\title{
Bazalt Ana Materyali ve Farklı Topografik Pozisyonlar Üzerinde Olușmuș Toprakların Bazı Topografik ve Fiziko- Kimyasal Özellikleri Arasındaki Doğrusal Regresyon Modellerinin Belirlenmesi
}

\author{
Imanverdi EKBERLi Orhan DENGIZ* \\ Ondokuz Mayıs Üniversitesi, Ziraat Fakültesi Toprak Bilimi ve Bitki Besleme Bölümü, SAMSUN \\ *sorumlu yazar e-mail (corresponding authore-mail): odengiz@omu.edu.tr
}

Geliș tarihi (Received) : 28.12.2016

Kabul tarihi (Accepted): 17.02.2017

Öz

Bu çalıșmanın amacı, farklı topografya ve arazi kullanım-örtü altında ancak, benzer jeolojik materyal üzerinde olușmuș altı farklı toprak profilinin zamana bağlı olarak lokal değișimlerinin incelenmesi ve eğim ile beraber ele alınan bazı fiziksel ve kimyasal toprak özellikleri arasında doğrusal regresyon modellerinin olușturulmasıdır. Bu kapsamda, Samsun-Bafra karayolunun güneyinde, Engiz Beldesine bağı Dağköy mevkii alanı içerisinde farklı topografik pozisyonlarda (tepe üstü düzlük/plato, yamaç, etek ve taban arazi) yer alan bazaltik ana materyal üzerinde olușmuș topraklarda fiziksel, kimyasal ve morfolojik özellikler belirlenmiș ve sınıflamaları yapıımıștır. Araștırma sonucuna göre, toprakların gerek arazi morfolojik incelemeleri gerekse de alınan toprak örneklerinde yapılan laboratuvar analizler sonucu, yamaç arazilerde yer alan topraklar, Soil Taksonomi sınıflandırmasına göre Lithic Ustorthent alt grubunda sınıflandırıırken, düz düze yakın eğimli taban ve tepe üstü/plato düzlüklerinde yer alan topraklar ise Typic Haplustert olarak sınıflandırılmıștır. Farklı toprak horizonlarının bazı topografik, fiziksel ve kimyasal özellikleri arasında korelasyon matrisleri belirlenmiștir. Ayrıca pedonlara ait genetik horizonların özellikleri arasında doğrusal regresyon modelleri olușturulmuștur. Çarpım, kare, kare kök içeren polinomlarla ifade edilen regresyon modellerinin regresyon katsayıları daha yüksek bulunmuștur.

Anahtar Kelimeler: Doğrusal regresyon model, toprak olușumu, bazalt ana materyal

\section{Determination of Liner Regression Model Between Some Topographic and Physico-chemical Properties of Soils Formed on Different Topographic Position and Basalt Parent Material}

\section{Abstract:}

The aim of this study is to investigate local variation of six soil pedons with time under different topographic position and land use-cover but over similar geologic material and to determine to generate liner regression models between slope, elevation and physico-chemical soil properties. In this concept, the main subjects in investigated six soil pedons that formed on basaltic parent material and different topographic positions and land use and land cover located in south of Samsun-Bafra highway and Engiz-Dağköy district were determine physical and chemical properties, and were classiffed. According to results which were obtained from both morphological properties in field study and analysis of soil samples in laboratory while soils located on high slope degree of transect were classified in Soil 
Taxonomy as Lithic Ustorthent, soils formed on almost flat land were classified as Typic Haplustert. In addition, it was created liner regresion models between genetic horizons of pedons

Key Words: Liner regresion model, soil formation, basalt parent matrial

\section{GíRiș}

Toprakların fiziksel ve kimyasal özellikleri, diğer çevresel faktörlerle beraber, toprak olușum süreçlerine, verimliliğe ve bitki gelișimine önemli düzeyde etki yapmaktadır. Fiziksel ve kimyasal özelliklerin değerleri ve değișimleri; toprakların katı, sıvı, gaz bileșenlerini ve oranlarını, bu bileșenlerin karșılıklı etkisini ve etkisel değișimlerini belirlemektedir. Dolayısıyla, toprakların fiziksel ve kimyasal özelliklerin belirlenmesi, verimliliğin korunması, tahmin edilmesi ve artırımasına yönelik yöntemlerinin belirlenmesinde gerekli olmaktadır.

Birçok araștırmacılar, toprakların fiziksel ve kimyasal özellikleri, strüktürel dayanaklılığı ve erozyona karșı duyarıı̆ı̆ı, bitki gelișiminde etkileyici faktörler olan tarla kapasitesi ve devamlı solma noktası değerlerini önemli șekilde etkilediğini belirtmișlerdir (Gülser vd., 2003; Gülser, 2004). Zaydelman (1987), toprakların infiltrasyon kapasitesi bünye ile yakından ilișkili olduğu için, kapalı dren aralıklarının toprakların bünye özelliğine göre belirlenebildiğini, dolayısıyla ağır bünyeli topraklarda dren aralıklarının az olması gerektiğini bildirmektedir. Ekberli ve Kerimova (2005; 2008), Azerbaycan'ın kurak iklime sahip Șirvan bölgesinin sulanan topraklarının bazı fiziksel ve kimyasal parametrelerinin değișimini; toprakların pH, değișebilir Na, bazı değișebilir bazik katyonların ( $\mathrm{Na}, \mathrm{Ca}, \mathrm{Mg}$ ) toplamı, humus ve $<0.001 \mathrm{~mm}$ fraksiyonları arasında fonksiyonel ilișkileri belirlemișlerdir. Araștırmacılar, toprakların fiziksel-kimyasal parametreleri arasındaki fonksiyonel ilișkilerin verimin tahmininde de kullanılmasının mümkün olduğunu bildirmișlerdir. Yine, Ekberli vd. (2009) tarafından Türkiye'nin Çankırı-Kızılırmak Havzasının alüviyal topraklarında yürütülen bir araștırmada, topraktaki tuz miktarı ile toprağın bazı fiziksel-kimyasal özellikleri arasındaki doğrusal ampirik ilișkiler belirlenmiștir. Elde edilen ampirik ilișkilerin, benzer özelliklere sahip bölge topraklarındaki tuz miktarının hesaplanmasında kullanılabilirliğini bildirmișlerdir.

Toprak ișleme süreçleri yöntemlerinin bilimsel temelinin belirlenmesinde, çeșitli topraklarda fiziksel ve kimyasal özelliklerin optimum değișim aralıklarının saptanması önemlidir. Zhumabekov (2005), toprakların plastiklik, yapıșkanlık, sıkılık, direnç gibi fiziksel-mekaniksel özelliklerinin tarım ișlemlerinde önemli olduğunu göstererek, Kırgızistan'ın temel toprak tiplerinde, bu özelliklerin toprak nemine bağı olarak değișimini incelemiștir. Toprak neminin \%15.8-42.3 arasında değișiminde, plastiklik sayısının 4.1-15.9; nemin \% 11 .2-30.6 arasında değișiminde iseyapıșkanlığın 6.9-40.5 g/ $\mathrm{cm}^{2}$ arasında değiștiğini bildirmiștir. Mısır bitkisi altındaki sulanan ve sulanmayan toprakların \%15.3-24.6 nem durumunda, direncin $0.50-0.65 \mathrm{~kg} \mathrm{~cm}^{-2}$ arasında olduğunu göstermiștir. Utkaeva (2007) tarafından, podzolik, allüvüyal, gri orman, çernezyom (tipik, yıkanmıș, vertik), solonetzic topraklarının fiziksel özellikleri değerlendirilmiș ve çeșitli antropojen etkiler sonucunda humus, nem, su tutma kapasitesi vb. gibi özelliklerin değișimi incelenmiștir. Çeșitli ıslah yöntemleri kullanılarak, toprakların optimum su bilançosunun yapılmasında da fiziksel özelliklerin belirlenmesi gereklidir. Korolev (2008), çernezyem topraklarda yapılan bir araștırmada sulama sonucunda toprağın temel fiziksel özelliklerinin değișimini incelemiștir. Sulama sonucunda, toprağın yukarı horizonlarında kil ve 0.01 mm'den küçük zerreciklerde azalma eğiliminin olduğunu; strüktürün düșük ve orta düzeyde, özgül ağırlık, toplam mesamelik ve hava tutumunun düșük düzeyde bozulduğunu göstermiștir. Purtova ve Zimina (2007) tarafindan yapılan bir araștırmada, kahverengi orman topraklarının yüzey horizonlarında (fitogenik alanlarda) fiziksel-kimyasal özelliklerin değișimi ve özellikler arasındaki ilișkiler belirlenmiștir. Fitogenik alanlarda humus miktarının (\%3.42-15.27) ve rezervinin (0-20 cm katmanında 72.0-228.0 t ha') yüksek, pH değerlerinin ise (2.74-6.16) düșük öldüğünü göstermișlerdir.

Toprak özellikleri arasındaki ampirik modeller, deneysel olarak elde edilen parametrelerin karșılıklı etkisini göz önüne alarak yapılmaktadır. Olayın mahiyetine varmadan sebep $\left(\mathrm{x}_{1}, i=1, \mathrm{n}\right) \rightarrow$ sonuç $(y)$ ilișkisini $(y=f(x))$ belirlemekte ve 
uygulamaya yönelik özelliğe sahip olmaktadır. Araștırılan ekosistemin (toprağın) özelliklerini ifade eden basit matematiksel ilișkilerin yapılmasına imkan veren parametrelerin nispeten az sayıda bulunması, regresyon modellerinin yapılmasının temel kısmı olmaktadır. Regresyon modellerine dâhil olan parametrelerin fazla olması (>20-30) modellerin uygulanabilirliğini zorlaștırmaktadır. Yukselen-Aksoy ve Kaya (2010), toprakların fiziksel ve kimyasal özellikleriyle, özgül yüzey alanı arasındaki ilișkilerin belirlenmesinde regresyon denklemlerinden kullanılmıșlardır. Elde edilen denklemlerin, benzer fiziksel ve kimyasal özelliklere sahip topraklarda kalibre edilmesinin gerekliliğini bildirmișlerdir. Simon ve Garcia (1999) tarafından yapılan bir çalıșmada, toplam çözünür tuzlarla (S), EC değerleri arasındaki ilișki ikinci dereceden regresyon denklemle $\mathrm{S}=28.320 \mathrm{EC}+0.2858$ $E C^{2}, r=0.969$, RMS $\left.=61.5\right)$ ifade edilmiștir. Azerbaycan'ın Mil ovası topraklarının verimlilik düzeylerinin deneysel ve matematiksel olarak değerlendirilmesinde, agroekolojik, agrofiziksel ve agrokimyasal özellikleri kapsayan kavramsal modeller olușturulmuș, bu özelliklerle verimlilik arasındaki ilișkiler çok değișkenli doğrusal regresyon denklemler ile ifade edilmiștir (Bayraklı vd., 1999). Candemir ve Gülser (2012) yaptıkları bir araștırmada, alkali toprakların su iletkenliğine etki yapan faktörleri belirleyerek, su iletkenliğinin tahmininde birinci ve ikinci derecedendoğrusal regresyon denklemleri kullanılmıșlardır. Topraklarda doygun hidrolik iletkenliğin tahmininde de birinci ve ikinci dereceden pedotransfer ilișkilerin kullanılması mümkün olmaktadır (Gülser vd., 2007). Bir çok araștırmacılar (Oian vd., 1996; Li vd., 1998; Carlona vd., 2004; Verachtert vd., 2011 ; Liu vd., 2014; Bosch vd., 2016; Silva Chagas vd., 2016) tarafından toprak parametrelerinin karșilıklı etkisine bağlı olarak çeșitli regresyon ilișkiler (doğrusal ve doğrusal olmayan) yapılmakta ve tahmin süreçlerinde kullanılmaktadır.

Bu araștırmada, farklı topografik pozisyonlarda ve aynı ana materyal (bazalt) üzerinde olușmuș toprakların genetik horizonlarına ait bazı fiziksel ve kimyasal özelliklerinin belirlenmesi; eğim ve yükselti gibi topografik parametrelerle fiziksel ve kimyasal toprak özelliklerinin karșılıklı etkisini ifade eden korelasyon matrisinin olușturulması; karșıılıkı etkisi önemli olan özellikler arasında doğrusal regresyon modellerinin belirlenmesi hedeflenmiștir.

\section{MATERYAL ve YÖNTEM}

Araștırma sahası Engiz Çayı havzası içerisindedir. Engiz Çayı Havzası Karadeniz Bölgesi'nin Orta Karadeniz bölümünde, Bafra Ovasının kuzeyinde, Samsun ili sınırları içerisinde yer alır. Dağköy mevkii alanı içerisinde deniz seviyesinden 20 m ile 300 m arasında yükselti değișkenliğinde bulunmaktadır. Araștırma sahası ve yakın çevresinde yüzeylenen en geniș birim Yenikonak formasyonudur. Volkano sedimanter kayaçlardan olușmaktadır. Büyük çoğunluğu tüf, tüfit, bazalt, kumlu kireçtașı ve marn ara seviyeli kumtașı-șeyl ardalanmasından olușmaktadır. Dikkate alınan bazalt ana materyali üzerinde olușan topraklarda mera alanları ile kuru tarım yapılan alanlar yer almakta olup çok az olsa da meșelerden olușan ormanlık alanlar mevcuttur. Mera alanlarında yaygın olan bașlıca otsu familyalar șunlardır; lahanagiller (Cruciferae), buğdaygiller (Gramineae), maydonozgiller (Umbelliferae), papatyagiller (Compositae), baklagiller (Fabaceae), gülgiller (Rosaceae). Kuru tarım yapılan alanlarda da çoğunlukla buğday tarımı yapılmaktadır.

Araștırma sahası içerisinde ölçüm istasyonu bulunmamaktadır. Bu yüzden saha çevresindeki istasyonlar esas alınmıștır. Araștırma sahasında yılın en soğuk ayı Șubat'tır $\left(5.6^{\circ} \mathrm{C}\right)$. En sıcak aylar ise Temmuz ve Ağustos aylarıdır $\left(22.6^{\circ} \mathrm{C}\right)$. Yılın dört ayında (Aralık, Ocak, Șubat, Mart) ortalama sıcaklıklar $10^{\circ} \mathrm{C}$ 'nin altında kalırken Nisan ayından itibaren yükselmektedir. Illkbahar dönemlerinde düzenli bir sıcaklık artıșı ve sonbahar dönemlerinde düzenli bir azalma görülmektedir (Çizelge 1). Araștırma sahasında ortalama yağıș miktarı yaklașık 800 mm'lerde değișir. Uzun yıllar aylık yağıș ortalamaları ise en düșük Temmuz 130.9 $\mathrm{mm}$ ) ve Ağustos (42.2 mm) en yüksek ekim ise Ekim $(101.6 \mathrm{~mm})$ aylarındadır. Yaz aylarının bitimiyle Eylül ayında artan yağıș miktarı Ekim ayında belirgin șekilde yükselmektedir. Yağıșın mevsimlere göre dağılıșı incelendiğinde en fazla yağıșın sonbahar mevsiminde en az yağıșın ise yazın düștüğü görülmektedir. Buna göre çok düzenli olmasa da yağıșların bütün yıla dağıldığını söylemek mümkündür.

Buharlașma eğrisi Nisan ayı ortalarından Eylül ayının sonlarına kadar yağıș eğrisinden yüksektir. Nisan sonlarından Haziran sonlarına kadar birikmiș su kullanılmıștır. Bu yüzden bu aylarda kuraklık etkili değildir. Temmuz ayından itibaren Eylül 


\section{toprâj}

Çizelge 1. Bafra'nın uzun yıllar (1975-2010) ortalama aylık yağıș ve sıcaklık dağııımı

Table 1. Long term (1975-2010) mean month precipitation and tempereture distribution of Bafra

\begin{tabular}{llllllllllllll}
\hline Aylar & $\mathrm{O}$ & $\mathrm{S}$ & $\mathrm{M}$ & $\mathrm{N}$ & $\mathrm{M}$ & $\mathrm{H}$ & $\mathrm{T}$ & $\mathrm{A}$ & $\mathrm{E}$ & $\mathrm{E}$ & $\mathrm{K}$ & $\mathrm{A}$ & $\mathrm{Y}$ Illık \\
\hline $\mathrm{T}$ & 5.7 & 5.6 & 7.2 & 10.9 & 15.1 & 19.8 & 22.6 & 22.6 & 19.0 & 14.9 & 11.0 & 7.6 & 13.5 \\
$\mathrm{P}$ & 81.6 & 65.7 & 60.3 & 56.9 & 47.8 & 48.3 & 30.9 & 42.2 & 61.3 & 101.6 & 98.3 & 100.6 & 794.4 \\
\hline
\end{tabular}

T: Sıcaklık $\left({ }^{\circ} \mathrm{C}\right), \mathrm{P}:$ Yağıș Ortalaması $(\mathrm{mm})$

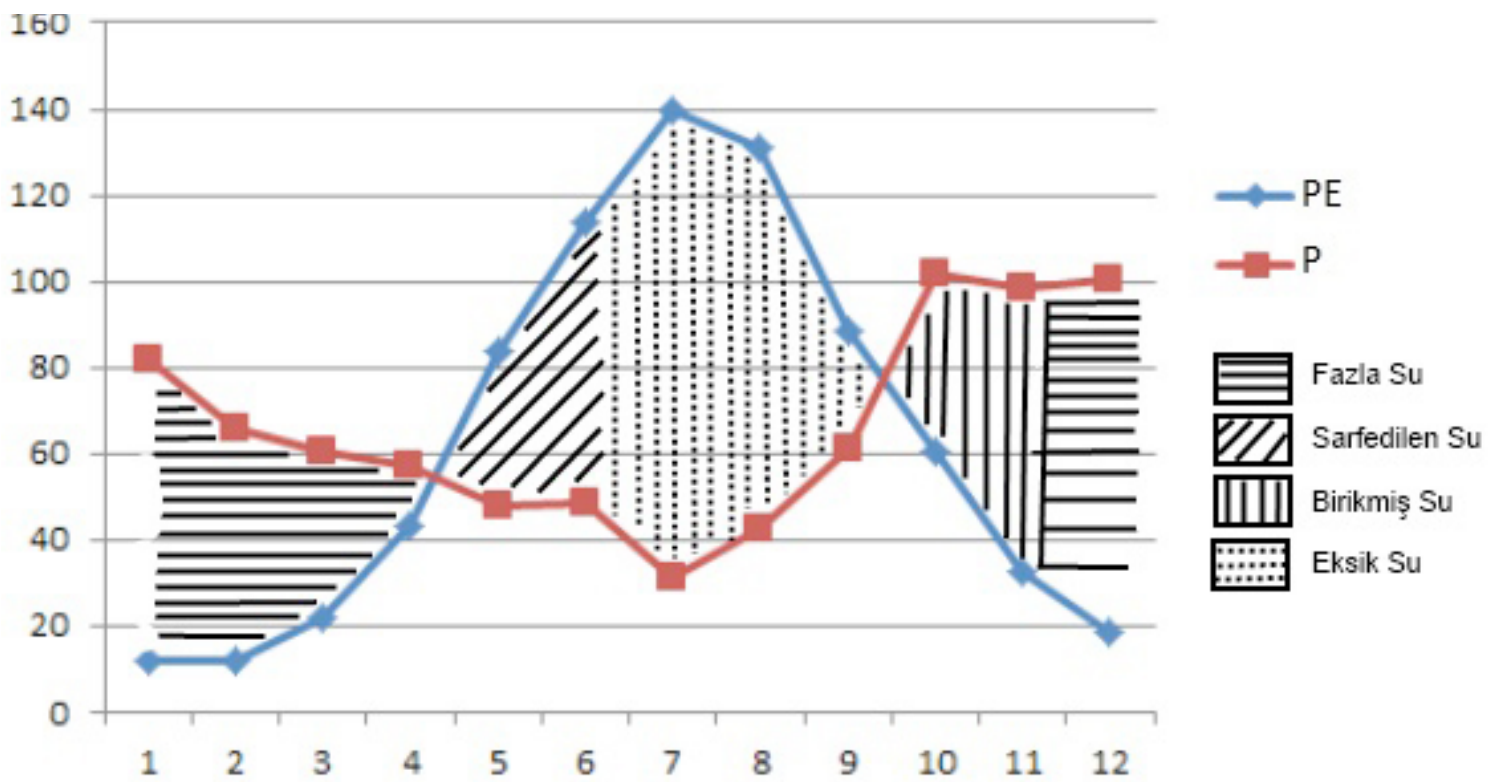

Șekil 1. Bafra'nın su bilançosu diyagramı (Thornthwaite, 1948)

Figure 1. Soil water budged of Bafra (Thornthwaite, 1948)

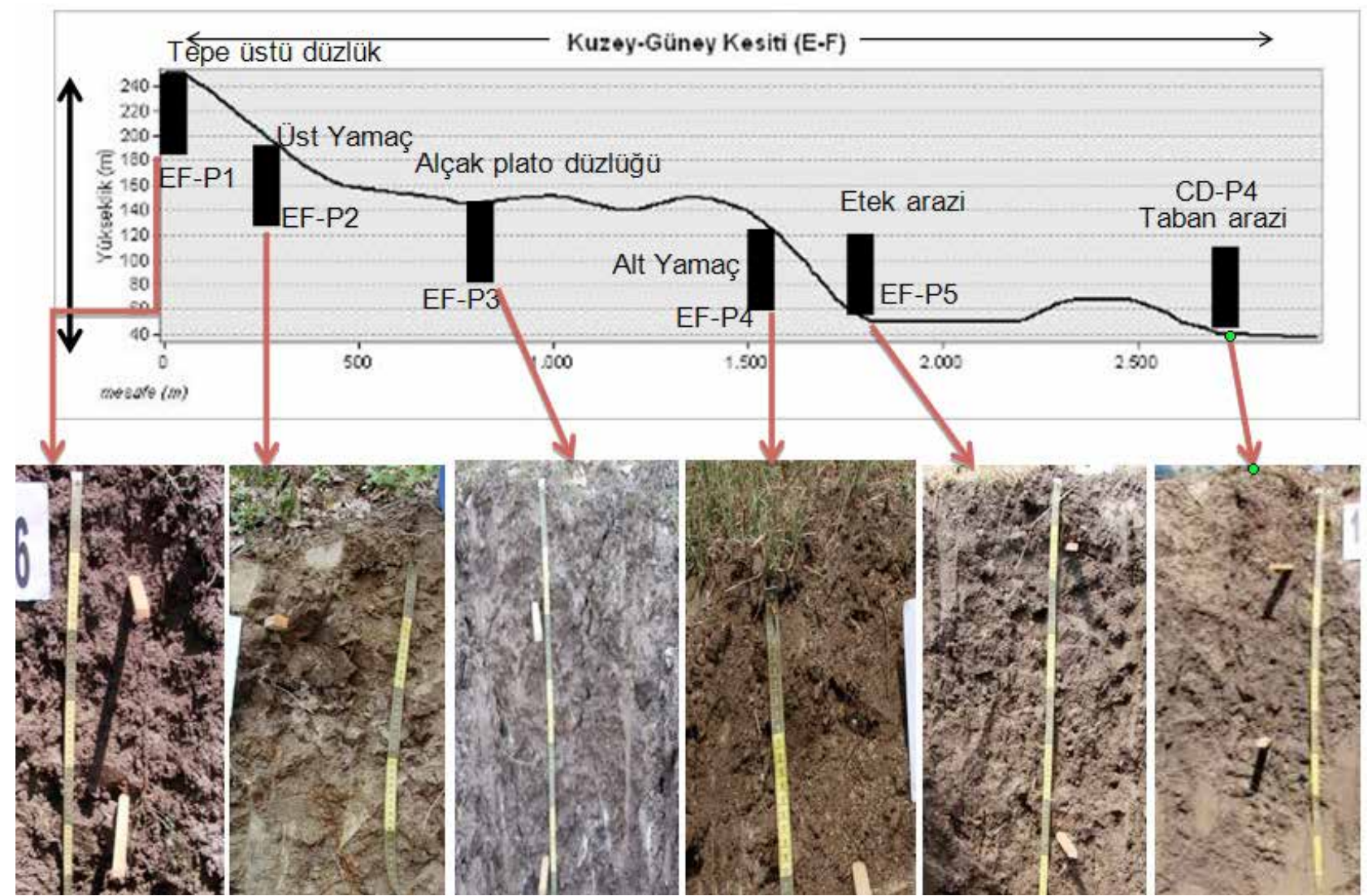

Șekil 2. Kuzey-Güney kesiti üzerinde yer alan farklı topografik pozisyonda açılan profiller

Figure 2. Soil profiles located on different topographic position at North and South transect

18 
ayının ortalarına kadar yaklașık üç buçuk aylık bir süre kurak geçmektedir (Șekil 1). Araștırma sahası iklim verileri De Martonne formülü kullanılarak değerlendirilmiștir. Bu formüle göre sahanın yıllık indis değeri 33.8'dir. Bu değere göre saha nemli iklim sahası içerisinde kalmaktadır. Araștırma sahası Köppen'e göre Orta İklimler Kușağı'nda yer alır.

Araștırma sahası toprakları deniz seviyesinden 20 m ile 300 m arasında yükselti değișkenliği içerisindeki farklı topografik pozisyonlarda (tepe üstü düzlük, yamaç, taban vb. araziler) yer alan bazaltik ana materyal üzerinde olușmaktadır. Kuzey-Güney doğrultusu üzerinde yer aldığı çalıșma alanı yaklașık $9.5 \mathrm{~km}^{2}$ olup, kesitleri üzerindeki arazi șekil ve açılan profillerin șematik gösterimi Șekil 2' de verilmiștir.

Arazide yapılan ön arazi keșif çalıșması yanı sıra alanda farklı topografya ve bazalt ana materyal üzerinde olușmuș farklı toprak yerleri sayısal topografik harita üzerine koordinatları aktarılmıștır. Arazide daha önce ön arazi keșfi ve büro çalıșmalarıyla belirlen profil çukur yerleri arazide GPS aleti kullanılarak yerleri belirlenmiș ve bu noktalarda profil çukurları açılmıștır. Açılan her bir profil çukurundan (1.5-2 m) horizon esasına göre toprak örneklemeleri yapılarak laboratuvara getirilmiș ve analiz ön ișlemlerine tabi tutulmuștur. Analizlere hazır hale getirilen topraklarda fiziksel ve kimyasal analizler yapılmıștır. Morfolojik çalıșmalarda Soil Survey Staff (1993)' den yararlanılmıștır. Toprakların morfolojik tanımlamaları için açılan her profil Soil Survey Staff (1993) tarafından belirtilen usuller esas alınarak incelenmiștir. Horizonların tanımı ve adlandırılması ise Soil Survey Staff (1 999)'a göre yapılmıștır.

Bünye (tekstür) bozulmuș toprak örneklerinde (Bouyoucous 1951), değișebilir katyonlar pH' sı 8.2'ye ayarlı sodyum asetat (NaOAc) kullanılarak (Rhoades, 1986), kireç serbest karbonatların tayininde Scheibler kalsimetresi kullanılarak (Soil Survey Staff, 1993), toprak reaksiyonu $(\mathrm{pH})$ saturasyon çamurunda $\mathrm{pH}$ metre kullanılarak (Soil Survey Staff, 1992; 2004), elektriksel iletkenlik saturasyon çamurunda kondaktivimetre aleti kullanılarak (Soil Survey Staff , 1992; 2004), organik madde Walkley-Black yönteminin Jackson tarafından modifiye edilmiș șekli ile yapılmıștır (Jackson, 1958).

Topraklarının bazı fiziksel-kimyasal özellikleri arasındaki doğrusal regresyon denklemlerinin belirlenmesinde $y=a_{0}+a_{1} x_{1}+a_{2} x_{2}+\ldots a_{n} x_{n} \quad$ (burada, $a_{0}, a_{1}, a_{2}, \ldots, a_{n}$ en küçük kareler yöntemiyle belirlenmesi gereken katsayılar; $y$-bağımlı; $x_{1}(i=\overline{1, n})$-bağımsız parametrelerdir) biçimindeki fonksiyonlardan kullanılmıștır. Modellerin olușturulmasında toprak özellikleri arasındaki korelasyon ilișkiler dikkate alınmıștır. Toprak Özelliklerinin bir birine karșılıklı etkisini göz önüne alarak, Özelliklerin çarpımını ve kare kökünü içeren terimlerden kullanılmıștır. Bağımlı değișken olarak pH, KDK, OM, kil, kireç değerleri alınmıș ve toprak özellikleri ile olan çoklu regresyon ilișkileri MiNiTAB-32 bilgisayar programını kullanılarak olușturulmuștur.

\section{BULGULAR ve TARTIȘMA}

\section{Toprakların Bazı Fiziksel, Kimyasal Özellikleri ve Sınıflaması}

Kuzey-Güney doğrultusunda yer alan farklı topografik pozisyonda (tepe üstü düzlük, üst yamaç, alçak plato düzlüğü, etek ve taban) ve arazi kullanımlarında (tarım, orman ve mera) açılan altı farklı profile ait fiziksel ve kimyasal analiz sonuçları Çizelge 2' de verilmiștir.

Typic Haplustert olarak sınıflandırılan CD-P4 nolu profili, taban arazi üzerinde olușmuș düz düze yakın eğimli, derin topraklardır. Tüm profil kil bünyeli olup, kil \% 56.2 ile \% 78.2 arasında değișmektedir. Bu durum toprakların saturasyon durumlarını doğrudan etkilemeleri nedeniyle özellikle kil miktarının derinlikle artıșı, toprakların sature olma durumlarını da arttırmaktadır. KDK'ları yüzeyde $42.80 \mathrm{cmolkg}^{-1}$ olmasına karșın derinlere doğru bu miktar düșüș göstermekte ve 39.78 cmol. $\mathrm{kg}^{-1}$ olmaktadır. Bu azalma kil miktarındaki bir miktar artmasına karșın, organik kökenli kollaidal maddelerin azalmasından kaynakladığı söylenebilir. Organik madde miktarı ise yüzeyde \% 1.65 olmasına karșın $65 \mathrm{~cm}$ den sonra daha da azalarak \% 0.14'e düșmektedir. Toprak reaksiyon hafif bazik olup pH değerleri 7.05 ile 8.25 arasında değișmektedir. Kireç profilde çok az miktarda olup yüzeyde \% 0.20 iken derinde bir miktar artarak \% 2.67 olmaktadır. Topraklarda baskın değișebilir katyonlar Ca ve Mg iyonlarıdır. Topraklarda tuzluluk ve alkalilik problemi görülmemektedir.

Etek arazi üzerinde açılan ve Vertic Haplustept olarak sınıflandırılan EF-P5 kodlu toprak profili, orta derin ve ağır bünyelidir. 66 cm derinliğe kadar kil \%58.3 ile \%61. 9 arasında değișmektedir. KDK'ları yüzeyde organik madde miktarı ve kil 
içeriği nedeniyle $43.70 \mathrm{cmolkg}^{-1}$ olmasına karșın 66 cm'den sonra $22.77 \mathrm{cmol}^{\mathrm{kg}}{ }^{-1}$ düșmektedir. Benzer șekilde organik madde miktarı içinde geçerli olup yüzeyde \% 2.21 olmasına karșın yüzey altı katmanda $\% 0.55^{\prime}$ e düșmektedir. Toprak reaksiyon bazik olup $\mathrm{pH}$ değerleri 8.12 ile 8.28 arasında değișmektedir. Kireç profilde çok az miktardadır ve \%0.79-1.75 arasında değișmektedir. Topraklarda baskın değișebilir katyonlar Ca ve $\mathrm{Mg}$ iyonlarıdır. Topraklarda tuzluluk ve alkalilik problemi görülmemektedir.

EF-P4 kodlu profil Kuzey-Güney doğrultusunda yer alan kesiti üzerinde deniz seviyesinden 135 m yükseklikte yer alan profil olup, Lithic Ustorthent olarak sınıflandırılmıștır. Profilin bulunduğu alan fizyografik açıdan yamaç arazidir. Yüzey örtüsü çok zayıf olması ve dik eğimli olmaları nedeniyle erozyon siddeti fazla, bu nedenle topraklar cok sığ $(19 \mathrm{~cm})$ derinliğe sahiptirler. Yüzey toprakları orta bünyeli olup kumlu kil tındır. KDK ve organik madde içerikleri yüzey toprağında $4185 \mathrm{cmol}$. kg-1 ve \% 3.37 dir. Toprak reaksiyonu hafif alkalin olup, pH değerleri 7.89' dir. Kireç profilde çok az olup \%0.39'dur. Topraklarda baskın değișebilir katyonlar Ca ve Mg iyonlarıdır. Topraklarda tuzluluk ve alkalilik problemi görülmemektedir.

Çizelge 2. Çalıșma toprakların fiziksel ve kimyasal analiz sonuçları, yükselti ve arazi kullanım durumları

Table 2. Physical and chemical analysis results of studied soils and their elevation and land use

\begin{tabular}{|c|c|c|c|c|c|c|c|c|c|c|c|c|c|}
\hline \multirow[t]{2}{*}{ Horizon } & \multirow[t]{2}{*}{$\begin{array}{l}\text { Derinlik } \\
\text { (cm) }\end{array}$} & \multirow[t]{2}{*}{$\mathrm{pH}$} & \multirow[t]{2}{*}{$\begin{array}{c}\mathrm{EC} \\
\mathrm{dS} \cdot \mathrm{m}^{-1}\end{array}$} & \multirow[t]{2}{*}{$\begin{array}{c}\text { Kireç } \\
\%\end{array}$} & \multirow[t]{2}{*}{$\begin{array}{l}\mathrm{OM} \\
\%\end{array}$} & \multirow[t]{2}{*}{$\begin{array}{c}\text { KDK } \\
\mathrm{cmol} . \mathrm{kg}^{-1}\end{array}$} & \multicolumn{3}{|c|}{$\begin{array}{l}\text { Değișebilirler Katyonlar } \\
\text { cmol. } \mathrm{kg}^{-1}\end{array}$} & \multicolumn{4}{|c|}{$\begin{array}{l}\text { Bünye Dağılımı } \\
\text { \% }\end{array}$} \\
\hline & & & & & & & $\mathrm{Na}+$ & $\mathrm{K}+$ & $\mathrm{Ca}+++\mathrm{Mg}++$ & Kil & Silt & Kum & Sinıf \\
\hline \multicolumn{14}{|c|}{ CD-P4 / Taban / Kuru Tarım / 25 m } \\
\hline A & $0-23$ & 7.50 & 0.17 & 0.20 & 1.65 & 42.80 & 0.22 & 1.67 & 40.91 & 56.2 & 23.1 & 20.7 & C \\
\hline Bss 1 & $23-65$ & 7.30 & 0.44 & 0.98 & 1.26 & 41.36 & 0.25 & 1.47 & 39.64 & 62.6 & 12.8 & 24.5 & C \\
\hline Bss2 & $65-106$ & 8.25 & 0.17 & 1.10 & 1.09 & 40.33 & 1.33 & 1.41 & 37.59 & 68.4 & 15.8 & 15.8 & $C$ \\
\hline C & $106+$ & 8.14 & 0.11 & 2.67 & 0.14 & 39.78 & 1.35 & 1.40 & 36.04 & 78.4 & 2.8 & 18.8 & C \\
\hline
\end{tabular}

EF5 / Etek / Orman / 42 m

\begin{tabular}{|c|c|c|c|c|c|c|c|c|c|c|c|c|c|}
\hline A & $0-15$ & 8.28 & 0.26 & 0.79 & 2.21 & 43.70 & 0.36 & 0.36 & 42.97 & 58.3 & 20.0 & 21.7 & $C$ \\
\hline Bw & $15-66$ & 8.12 & 0.18 & 1.26 & 0.67 & 43.37 & 0.47 & 0.32 & 42.58 & 61.9 & 25.6 & 12.5 & C \\
\hline $2 \mathrm{Cr}$ & $66-106$ & 8.20 & 0.25 & 1.75 & 0.55 & 27.77 & 1.02 & 0.26 & 26.49 & 37.3 & 34.8 & 27.9 & $C L$ \\
\hline
\end{tabular}

EF-P4 /Alt Yamaç / Kuru tarım / 135 m

\begin{tabular}{|c|c|c|c|c|c|c|c|c|c|c|c|c|c|}
\hline$A$ & $0-19$ & 7.89 & 0.40 & 0.39 & 3.37 & 41.85 & 0.16 & 0.49 & 41.02 & 32.5 & 18.6 & 48.9 & $\mathrm{SCL}$ \\
\hline R & $19-32$ & - & - & - & - & & - & - & - & - & - & - & - \\
\hline
\end{tabular}

EF-P3 / Alçak plato düzlüğü / Orman / 160 m

\begin{tabular}{|c|c|c|c|c|c|c|c|c|c|c|c|c|c|}
\hline$A$ & $0-18$ & 7.06 & 0.44 & 1.08 & 1.88 & 47.28 & 0.24 & 0.32 & 46.71 & 54.4 & 22.6 & 23.1 & $C$ \\
\hline Bw & $18-57$ & 7.31 & 0.42 & 1.02 & 0.06 & 50.54 & 0.34 & 0.09 & 50.11 & 61.1 & 17.7 & 21.2 & C \\
\hline $\mathrm{Cr}$ & $57-87$ & 7.01 & 0.51 & 0.39 & 0.57 & 40.54 & 0.58 & 0.09 & 39.87 & 57.5 & 22.6 & 19.9 & C \\
\hline \multicolumn{14}{|c|}{ EF-P2 / Üst Yamaç / Orman/ 190 m } \\
\hline$A$ & $0-11$ & 6,74 & 0.35 & 0.09 & 1.54 & 28.70 & 0.35 & 0.43 & 27.92 & 22.0 & 21.8 & 56.2 & $S L$ \\
\hline $\mathrm{Cr}$ & $11-65$ & 7.01 & 0.20 & 0.29 & 0.87 & 17.66 & 0.54 & 0.12 & 17.00 & 14.6 & 9.3 & 76.1 & LS \\
\hline \multicolumn{14}{|c|}{ EF-P1/Tepe üstü düzlük / Mera / 251 m } \\
\hline$A$ & $0-12$ & 7.14 & 0.55 & 0.69 & 3.53 & 49.73 & 0.29 & 0.58 & 48.85 & 61.9 & 23.6 & 14.5 & C \\
\hline Bw1 & $12-41$ & 7.70 & 0.54 & 0.98 & 1.78 & 44.57 & 0.27 & 0.31 & 43.98 & 49.9 & 27.7 & 12.5 & C \\
\hline Bw2 & $41-84$ & 7.92 & 0.11 & 0.98 & 1.41 & 52.55 & 0.64 & 0.29 & 51.62 & 47.9 & 32.3 & 19.8 & $C$ \\
\hline $2 C k$ & 84-105 & 7.94 & 0.38 & 6.37 & 1.29 & 44.46 & 0.63 & 0.09 & 43.74 & 40.0 & 40.8 & 19.1 & C \\
\hline
\end{tabular}

EC: Elektiriksel iletkenlik, OM: Organik madde 
Typic Haplustept olarak sınıflandırılan EF-P3 kodlu profil, deniz seviyesinden 160 m yükseklikte yer alan alçak plato üzerinde olușmuș, hafif eğime sahip derin topraklardır. Üzerinde genellikle orman ve mera örtüsü bulunduran bu arazilerdeki topraklar, ağır bünyelidirler. Kil profilde \%54.4 ile \%61.1 arasında değișmektedir. Bu durum ağır bünyeye sahip profillerde olduğu gibi, toprakların doygunluk olma durumlarını doğrudan etkilemeleri nedeniyle özellikle kil miktarının derinlikle artıșı, toprakların suyla doygun olma durumlarını da arttırmaktadır. KDK'ları 40.54 ile $50.54 \mathrm{cmolkg}^{-1}$ arasında değișmektedir. Organik madde miktarı yüzeyde \% 1.88 iken derinlere doğru bu oran hızlı bir șekilde düșmektedir. Toprak reaksiyonu hafif bazik olup $\mathrm{pH}$ değerleri 7.01 ile 7.31 arasında değișmektedir. Kireç profilde çok az miktarda olup, yüzeyde \%0.39 iken derinde bir miktar artarak \% 1.08 olmaktadır. Topraklarda baskın değișebilir katyonlar Ca ve Mg iyonlarıdır. Topraklarda tuzluluk ve alkalilik problemi görülmemektedir.

Lithic Ustorthent olarak sınıflandırılan EF-P2 kodlu profil Kuzey-Güney doğrultusunda yer alan kesiti üzerinde deniz seviyesinden 190 m yükseklikte olup, fizyografik arazi șekli yamaçtır. Çok sığ derinliğe $(11 \mathrm{~cm})$ sahip, kumlu tın bünyelidirler. Kil ve organik madde içerikleri diğer profillere göre çok düșük seviyelerde olmaları nedeniyle KDK 17.66 ile $28.70 \mathrm{cmolkg}^{-1}$ arasında değișmektedir. Toprak reaksiyonu, hafif asit ile nötür olup, pH değerleri 6.74 ile 7.01 arasında değișmektedir. Kireç profilde çok az olup \%0.09 ile \%0.29 arasındadır. Topraklarda baskın değișebilir katyonlar Ca ve $\mathrm{Mg}$ iyonlarıdır. Topraklarda tuzluluk ve alkalilik problemi görülmemektedir.

EF-P1 kodlu profil Kuzey-Güney kesiti üzerinde deniz seviyesinden $251 \mathrm{~m}$ ile en yüksekte yer alan profil olup Typic Haplustept olarak sınıflandırıımıștır. Tepe üstü düzlükler üzerinde yer alan arazilerde yayılım göstermektedirler. Tüm profil kil bünyeli olup, kil \%40.0 ile \%61.9 arasında değișmektedir. Bu durum toprakların doygun olma durumlarını doğrudan etkilemeleri nedeniyle özellikle kil miktarının derinlikle artıșı, toprakların sature olma durumlarını da arttırmaktadır. KDK'ları yüksek kil içeriği nedeniyle 44.46 ile $52.55 \mathrm{cmolkg}^{-1}$ arasında değișmektedir. Toprak reaksiyon hafif bazik olup pH değerleri 7.14 ile 7.94 arasında değișmektedir. Kireç profilde az miktarda olup yüzeyde \% 0.69 iken derinde bir miktar artarak \%4.37 olmaktadır.
Topraklarda baskın değișebilir katyonlar Ca ve Mg iyonlarıdır. Topraklarda tuzluluk ve alkalilik problemi görülmemektedir.

\section{Farklı Toprak Horizonlarının Bazı Topografik, Fiziksel ve Kimyasal Özellikleri Arasındaki îlișkiler}

Araștırma toprağının A horizonlarının özellikleri arasındaki ilișkilere ait korelasyon katsayıları Çizelge 3'de verilmiștir. Kesit üzerinde yer alan toprakların $\mathrm{pH}$ değerleri ile silt ve yükseklik arasında yüksek negatif korelasyonlar, diğer özellikleri arasında ise zayıf ve çok zayıf ilișkiler bulunmuștur. $\mathrm{pH}$ değerlerinin sayısal olarak dar aralıkta (6.74-8.28) değișimi, diğer özelliklerin ise (örneğin Na, K, silt, kum) çok düșük değerlere sahip olması, korelasyon katsayılarının düșük olmasının nedenlerinden olabilmektedir. Yükseklik artıkça, atmosfer olaylarının (özellikle yağıș miktarı, çeșidi vb.) daha etkili olması sonucu, toprağın pH değerlerinin azalması mümkün olabilir. Toprağın EC değerleri, yükseklik ile çok önemli düzeyde pozitif ilișki vermiș, $\mathrm{OM}$ ve $\mathrm{K}$ ile ise korelasyon ilișki yüksek, fakat önemli düzeyde olmamaktadır. Kireç, OM, Na, K, silt miktarları geri kalan toprak özellikleriyle önemsiz düzeyde ilișki göstermiștir. Kireç ile KDK, Ca+Mg, kil ve kum arasında yüksek korelasyon, eğim ile ise orta șiddette negatif ilișki saptanmıștır. Toprak KDK' sı, Ca+Mg ile çok önemli pozitif, kil ile önemli pozitif, kum ile önemli düzeyde negatif, eğim ile ise orta șiddette negatif ilișkiler vermiștir. Ca+Mg ile kil ve kum miktarları arasında önemli düzeyde sırasıyla pozitif ve negatif, eğim ile ise orta șiddette negatif ilișkiler belirlenmiștir. Kil miktarı kum ile çok önemli, eğim ile ise önemli düzeyde negatif ilișkiler göstermiștir. Kum miktarıyla eğim arasındaki ilișki pozitif ve önemli bulunmuștur.

Kesit üzerinde yer alan toprakların B horizonlarının özellikleri arasındaki ilișkilere ait korelasyon katsayıları Çizelge 4'de gösterilmiștir. Toprakların $\mathrm{pH}$ değerleri ile EC, kireç, Na ve kum arasındaki korelasyon katsayılar yüksek olup, fakat önemli olmamaktadır. EC değeri diğer tüm toprak özellikleriyle, zayıf ilișkiler göstermiștir. Kireç ve OM ile diğer toprak parametreleri arasında zayıf ve orta șiddette korelasyonlar bulunmuștur. Kireç ile eğim arasında ise önemli düzeyde pozitif ilișki saptanmıștır. KDK ile Ca+Mg arasında çok önemli düzeyde pozitif ilișki, diğer parametreler arasında ise zayıf ve orta șiddette korelasyonlar 
Çizelge 3. A horizonlarına ait toprak parametrelerine ilișkin korelasyon matrisi

Table 3. Correlation matris of soil parametres for A horizons of soils

\begin{tabular}{|c|c|c|c|c|c|c|c|c|c|c|c|c|}
\hline & EC & Kireç & OM & KDK & $\mathrm{Na}$ & K & $\mathrm{Ca}+\mathrm{Mg}$ & Kil & Silt & Kum & Yükseklik & Eğim \\
\hline $\mathrm{pH}$ & -0.410 & 0.173 & 0.277 & 0.306 & -0.123 & 0.031 & 0.278 & 0.296 & -0.671 & -0.204 & -0.659 & 0.120 \\
\hline EC & & 0.431 & 0.651 & 0.345 & -0.063 & -0.606 & 0.376 & 0.019 & 0.163 & -0.036 & $0.922 * *$ & 0.089 \\
\hline Kireç & & & 0.204 & 0.735 & 0.046 & -0.500 & 0.778 & 0.628 & 0.079 & -0.601 & 0.138 & -0.455 \\
\hline OM & & & & 0.514 & -0.343 & -0.261 & 0.497 & 0.162 & -0.255 & -0.125 & 0.454 & 0.275 \\
\hline KDK & & & & & -0.329 & 0.054 & 0.997 ** & $0.865^{*}$ & 0.239 & $-0.843^{*}$ & 0.021 & -0.543 \\
\hline $\mathrm{Na}$ & & & & & & -0.344 & -0.269 & 0.036 & 0.181 & -0.055 & 0.115 & -0.305 \\
\hline K & & & & & & & -0.003 & 0.251 & 0.394 & -0.283 & -0.531 & -0.329 \\
\hline $\mathrm{Ca}+\mathrm{Mg}$ & & & & & & & & $0.872^{*}$ & 0.258 & $-0.852^{*}$ & 0.056 & -0.568 \\
\hline Kil & & & & & & & & & 0.452 & -0.995 ** & -0.207 & $-0.848 *$ \\
\hline Silt & & & & & & & & & & -0.539 & 0.288 & -0.773 \\
\hline Kum & & & & & & & & & & & 0.163 & 0.887 * \\
\hline Yükseklik & & & & & & & & & & & & 0.138 \\
\hline
\end{tabular}

** Korelasyon 0.01 düzeyinde çok önemli; *Korelasyon 0.05 düzeyinde önemli

belirlenmiștir. KDK ve yükseklikle yüksek pozitif ilișki belirlenmiștir. Na ile diğer özellikler arasındaki ilișkiler önemsiz olarak saptanmıștır. K değerleri, $\mathrm{Ca}+\mathrm{Mg}$ ile önemli negatif, yükseklik ve eğimle ise sırasıyla yüksek ve orta șiddette negatif korelasyonlar vermiștir. Kil miktarı silt ile önemli, yükseklikle ise çok önemli düzeyde negatif ilișkiler göstermiștir. Kum miktarının diğer tüm toprak özellikleriyle ilișkileri önemsiz düzeyde olup, pH'la yüksek, kireç, silt ve eğim ile orta șiddette negatif korelasyonlar vermiștir.
Araștırma topraklarının ana materyallerine yönelik incelenen değișkenlerine ilișkin korelasyon matrisi Çizelge 5'de verilmiștir. Çizelgeden de görüldüğü gibi, toprağın pH değeriyle, diğer tüm özellikleri arasındaki ilișkilerinin önemsiz olmasına rağmen, Na ile yüksek șiddette pozitif, kireç ve K ile orta șiddette pozitif, kum, yükseklik ve eğim ile ise orta șiddette negatif korelasyonlar saptanmıștır. Toprağın EC değerleriyle, kireç, kil, kum, eğim arasında zayıf; diğer özellikleriyle ise orta ve yüksek șiddette korelasyonlar bulunmuștur. Kireç

Çizelge 4. B horizonlarına ait toprak parametrelerine ilișkin korelasyon matrisi

Table 4. Correlation matris of soil parametres for B horizons of soils

\begin{tabular}{|c|c|c|c|c|c|c|c|c|c|c|c|c|}
\hline & $\mathrm{EC}$ & Kireç & $\mathrm{OM}$ & KDK & $\mathrm{Na}$ & K & $\mathrm{Ca}+\mathrm{Mg}$ & Kil & Silt & Kum & Yükseklik & Eğim \\
\hline $\mathrm{pH}$ & -0.754 & 0.617 & 0.201 & -0.246 & 0.749 & 0.073 & -0.282 & 0.114 & 0.371 & -0.693 & -0.152 & 0.285 \\
\hline EC & & -0.492 & 0.108 & -0.137 & -0.669 & -0.045 & -0.068 & -0.122 & -0.296 & 0.136 & 0.191 & -0.265 \\
\hline Kireç & & & -0.412 & -0.358 & 0.276 & -0.066 & -0.331 & 0.491 & 0.023 & -0.567 & -0.538 & $0.818^{*}$ \\
\hline OM & & & & -0.225 & 0.028 & 0.269 & -0.232 & -0.525 & 0.370 & -0.214 & 0.324 & -0.458 \\
\hline KDK & & & & & -0.273 & -0.755 & 0.993 ** & -0.647 & 0.566 & 0.245 & 0.755 & 0.069 \\
\hline $\mathrm{Na}$ & & & & & & 0.437 & -0.364 & 0.436 & -0.136 & -0.219 & -0.331 & -0.237 \\
\hline K & & & & & & & $-0.814^{*}$ & 0.608 & -0.704 & 0.322 & -0.719 & -0.543 \\
\hline $\mathrm{Ca}+\mathrm{Mg}$ & & & & & & & & -0.674 & 0.591 & 0.199 & 0.775 & 0.139 \\
\hline Kil & & & & & & & & & -0.837 * & 0.117 & -0.921 ** & 0.056 \\
\hline Silt & & & & & & & & & & -0.492 & 0.757 & 0.338 \\
\hline Kum & & & & & & & & & & & -0.139 & -0.497 \\
\hline Yükseklik & & & & & & & & & & & & -0.121 \\
\hline
\end{tabular}

** Korelasyon 0.01 düzeyinde çok önemli; *Korelasyon 0.05 düzeyinde önemli 
Çizelge 5. C horizolarına ait toprak parametrelerine ilișkin korelasyon matrisi

Table 5. Correlation matris of soil parametres for $C$ horizons of soils

\begin{tabular}{|c|c|c|c|c|c|c|c|c|c|c|c|c|}
\hline & EC & Kireç & OM & KDK & $\mathrm{Na}$ & K & $\mathrm{Ca}+\mathrm{Mg}$ & Kil & Silt & Kum & Yükseklik & Eğim \\
\hline $\mathrm{pH}$ & -0.443 & 0.597 & -0.205 & 0.327 & 0.767 & 0.513 & 0.264 & 0.385 & 0.278 & -0.554 & -0.515 & -0.554 \\
\hline EC & & 0.053 & 0.433 & 0.440 & -0.672 & -0.688 & 0.534 & -0.045 & 0.582 & -0.338 & 0.570 & -0.297 \\
\hline Kireç & & & 0.515 & 0.622 & 0.096 & 0.060 & 0.626 & 0.141 & 0.539 & -0.491 & 0.337 & -0.517 \\
\hline OM & & & & 0.013 & -0.759 & -0.753 & 0.106 & -0.669 & 0.640 & 0.225 & $0.914^{*}$ & 0.236 \\
\hline KDK & & & & & 0.182 & 0.237 & $0.993^{* *}$ & 0.725 & 0.303 & $-0.899 *$ & 0.088 & $-0.923^{*}$ \\
\hline $\mathrm{Na}$ & & & & & & $0.895^{*}$ & 0.073 & 0.675 & -0.342 & -0.427 & $-0.886^{*}$ & -0.450 \\
\hline K & & & & & & & 0.120 & 0.750 & -0.638 & -0.306 & -0.725 & -0.366 \\
\hline $\mathrm{Ca}+\mathrm{Mg}$ & & & & & & & & 0.649 & 0.382 & -0.877 & 0.183 & $-0.895^{*}$ \\
\hline Kil & & & & & & & & & -0.285 & -0.778 & -0.544 & -0.815 \\
\hline Silt & & & & & & & & & & -0.380 & 0.408 & -0.319 \\
\hline Kum & & & & & & & & & & & 0.257 & $0.995^{* *}$ \\
\hline Yükseklik & & & & & & & & & & & & 0.251 \\
\hline
\end{tabular}

miktarıyla OM, silt ve eğim arasındaki korelasyon orta, KDK, Ca+Mg ile ise yüksek olup, önemsiz düzeyde gerçekleșmiștir. OM, yükseklik ile önemli düzeyde çok yüksek pozitif korelasyon vermiștir. KDK miktarı, Ca+Mg ile çok önemli düzeyde pozitif korelasyon; kum ve eğimle ise önemli düzeyde çok yüksek negatif korelasyonlar göstermiștir. Na 'la K arasında önemli düzeyde çok yüksek pozitif, yükseklikle ise negatif korelasyonlar saptanmıștır. $\mathrm{Ca}+\mathrm{Mg}$ değerleriyle eğim arasında önemli düzeyde negatif yüksek korelasyon belirlenmiștir. Kil miktarı yükseklik ve eğimle sırasıyla orta ve yüksek șiddette negatif korelasyonlar göstermiștir. Silt ile diğer tüm toprak özellikleri arasındaki korelasyonlar önemsiz olup, zayıf, orta ve yüksek șiddette gerçekleșmiștir. Yükseklikle pozitif orta, eğim ile ise zayıf negatif korelasyon vermiștir. Topraktaki kum miktarı ile yükseklik arasında zayıf, eğim arasında ise çok önemli düzeyde çok yüksek korelasyon belirlenmiștir.

Korelasyon katsayısı parametreler arasında doğrusal ilișkiyi ifade ettiğinden, özellikler arasındaki bazı ilișkilerin düșük olmasının nedeni, doğrusal olmayan ilișkilerin mümkünlüğü, ilișkilerin doğrusallașma sürecinin kısa olmaması, bazı parametrelerin değișme aralıklarının dar olması, parametrelerin karșılıklı etkisinin farklılığı, yükseklik ve eğime bağlı olarak parametrelerin düzensiz değișimi, ana materyalin ilkin bileșenlerinin belirlenmesinin zorluğu, toprak profillerinin oluștuğu jeomorfolojik koșulların çok nadir durumlarda benzerlik göstermesi, yükseklik ve eğimin topraktaki makro süreçlerin hızına ve yönüne etkisi gibi durumlar olabilir.

\section{Farklı Toprak Horizonlarının Bazı Fiziksel ve Kimyasal Özellikleri Arasındaki Regresyon Modelleri}

Toprak özellikleri arasındaki regresyon modeller, özellikler arasındaki nicel ilișki durumunu ifade etmektedir. Bu modeller, deneysel değerleri genelleștirmekte; yerel, bölgesel ve global düzeyde olușturulmakta, toprak ve iklim koșullarına göre farklılık göstermektedir.

Regresyon modellerinin olușturulmasında toprak parametrelerine ilișkin korelasyon analizi sonuçları dikkate alınmıștır. Aralarındaki korelasyon ilișkileri çok düșük düzeyde olan parametreler modellerin olușturulmasında kullanılmamıștır. Kesit üzerinde yer alan toprakların A horizonlarının bazı özellikleri arasındaki regresyon modelleri așağıdaki biçimde belirlenmiștir (Çizelge 6)

Çizelge 6'dan da görüldüğü gibi, toprakların A horizonlarının bazı özellikleri arasındaki regresyon modellerinin regresyon katsayıları (regresyon denklemlerinin belirleme katsayısı) yüksek ve çok yüksek düzeyde olup, 0.615-0.998 arasında değișmektedir. 1. ve 4. modellere göre, organik madde, kil, Ca+Mg özellikleri KDK'nın artıșını etki yapmaktadır. Özelliklerin çarpımını (OM, Kil) ve kare kökünü $(\sqrt{\text { Kil }})$ ifade eden terimlerin modele dahil edilmesi, modellerin performansını 
Çizelge 6. Toprakların A horizonlarının bazı özellikleri arasındaki regresyon modelleri

Table 6. Regression models between some parameters for A horizons of soils

\begin{tabular}{|c|c|c|}
\hline & & $R^{2}$ \\
\hline 1. & $\mathrm{KDK}=12.2+2.15 \mathrm{OM}+0.485 \mathrm{Kil}+0.142 \mathrm{Eğim}$ & 0.902 \\
\hline 2. & KDK $=9.5+22.2 \mathrm{OM}+0.512$ Kil -0.627 Eğim $-0.310 \mathrm{OM} \cdot$ Kil & 0.961 \\
\hline 3. & $\mathrm{KDK}=1.16+1.01(\mathrm{Ca}+\mathrm{Mg})-0.0085 \mathrm{Kil}$ & 0.994 \\
\hline 4. & $\mathrm{KDK}=-17.8+0.938(\mathrm{Ca}+\mathrm{Mg})-0.518 \mathrm{Kil}+6.79 \sqrt{\mathrm{Kil}}$ & 0.996 \\
\hline 5. & $\mathrm{OM}=-3.02$ + $0.0156 \mathrm{Kil}+0.092 \mathrm{KDK}+0.0532$ Eğim & 0.704 \\
\hline 6. & $\mathrm{OM}=22.9+0.777 \mathrm{Kil}+0.150 \mathrm{KDK}+0.0863 \mathrm{Eğim}-9.56 \sqrt{\text { Kil }}$ & 0.970 \\
\hline 7. & Kil $=78.4-1.08$ Kum + 0.173 Eğim & 0.996 \\
\hline 8. & Kil $=57.7-1.72$ Kum + 0.157 Eğim $+7.54 \sqrt{\text { Kum }}$ & 0.998 \\
\hline 9. & Kirec $=-1.27+0.0495(\mathrm{Ca}+\mathrm{Mg})-0.0049$ Kil & 0.615 \\
\hline 10. & Kireç $=23.6+1.06(C a+M g)-0.395$ Kil $-13.0 \sqrt{C a+M g}+5.2 \sqrt{K i l}$ & 0.713 \\
\hline
\end{tabular}

** Korelasyon 0.01 düzeyinde çok önemli; *Korelasyon 0.05 düzeyinde önemli

artırmıștır. Aynı durum 5. ve 10. modeller için de söz konusu olmaktadır. 5. ve 6. modellerde, kil, KDK ve eğimin organik madde artıșına etkisi gözükmektedir. 7. ve 8. modellere göre, kil miktarının değișimine kum negatif, eğimin ise pozitif etkiyapmaktadır. Kireç miktarına, Ca+Mg'nin pozitif, kilin ise negatif etkisi 9. ve 10. modellerden gözükmektedir. Toprakların B horizonlarının bazı özellikleri arasındaki regresyon modellerinin $\left(R^{2}\right)$ orta șiddette, yüksek ve çok yüksek düzeyde olup, 0.418-0.998 arasında değișmektedir (Çizelge 7).

En düșük regresyon katsayısı $\left(R^{2}=0.418\right) 9$. regresyon modelinde saptanmıștır. Regresyon katsayısının düșük olması, eğim faktörünün kil ve kum miktarına düzensiz etkisinden kaynaklanmıș olabilir. Doğrusal olmayan terimler regresyon modellerinin korelasyon katsayılarının yükselmesine neden olmaktadır.

Toprakların C horizonlarına ait bazı özellikler arasındaki regresyon modelleri Çizelge 8'de verilmiștir. Modellerin regresyon katsayısı 0.5530.997 arasında değișmekte; en düșük regresyon katsayısı kireç ile Ca+Mg, kil ve eğim arasında, en yüksek ise KDK'nı ifade eden modellerde bulunmuștur. Regresyon modellerin, özelliklerin karekökünü ve karesini içeren polinomlarla ifadesi, yüksek regresyon katsayısı vermiștir. Bu ise, genel olarak tahminin önem düzeyini artırmaktadır.

Çizelge 7. Toprakların B horizonlarının bazı Özellikleri arasındaki regresyon modelleri

Table 7. Regression models between some parameters for $B$ horizons of soils 8

\begin{tabular}{|c|c|c|}
\hline 1. & $\mathrm{pH}=5.41-2.34 \mathrm{Na}+5.16 \sqrt{\mathrm{Na}}$ & 0.686 \\
\hline 2. & $\mathrm{pH}=6.86+1.29 \sqrt{\mathrm{Na}}$ & 0.614 \\
\hline 3. & KDK $=97.7-7.92 \mathrm{OM}-0.708$ Kil -0.680 Eğim & 0.930 \\
\hline 4. & KDK $=142-39.6 \mathrm{OM}-1.44 \mathrm{Kil}-0.643 \mathrm{Eğim}+0.536 \mathrm{OM} \cdot \mathrm{Kil}$ & 0.950 \\
\hline 5. & $\mathrm{KDK}=3.75+0.908(\mathrm{Ca}+\mathrm{Mg})+0.0258 \mathrm{Kil}$ & 0.987 \\
\hline 6. & $\mathrm{KDK}=168+0.945(\mathrm{Ca}+\mathrm{Mg})+2.99 \mathrm{Kil}-44.5 \sqrt{\mathrm{Kil}}$ & 0.998 \\
\hline 7. & $\mathrm{OM}=11.3-0.0830$ Kil -0.111 KDK -0.0896 Eğim & 0.933 \\
\hline 8. & $\mathrm{OM}=59.7+0.777$ Kil -0.107 KDK -0.0550 Eğim $-13.0 \sqrt{\text { Kil }}$ & 0.981 \\
\hline 9 . & Kil $=39+5.1$ Kum - 15.3 Eğim - $0.126(\text { Kum })^{2}+1.59(\text { Eğim })^{2}$ & 0.418 \\
\hline 10. & Kireç $=0.929-0.00543(\mathrm{Ca}+\mathrm{Mg})+0.00361 \mathrm{Kil}+0.0417$ Eğim & 0.906 \\
\hline 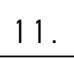 & Kireç $=18.9+0.384(\mathrm{Ca}+\mathrm{Mg})-0.00050 \mathrm{Kil}+0.0561 \mathrm{Eğim}-5.27 \sqrt{C a+M g}$ & 0.981 \\
\hline
\end{tabular}


Çizelge 8. Toprakların C horizonlarının bazı Özellikleri arasındaki regresyon modelleri

Table 8. Regression models between some parameters for $C$ horizons of soils

\begin{tabular}{|c|c|c|}
\hline & & $R^{2}$ \\
\hline 1. & $\mathrm{pH}=5.38+2.55 \sqrt{\mathrm{Na}}$ & 0.623 \\
\hline 2. & $\mathrm{pH}=-7.45-14.9 \mathrm{Na}+30.7 \sqrt{\mathrm{Na}}$ & 0.811 \\
\hline 3. & $\mathrm{KDK}=4.9+18.5 \mathrm{OM}+0.433 \mathrm{Kil}-0.386$ Eğim & 0.992 \\
\hline 4. & KDK $=0.97+0.924(C a+M g)+0.0646$ Kil & 0.997 \\
\hline 5. & KDK $=3.77+0.947(\mathrm{Ca}+\mathrm{Mg})+0.142$ Kil $-1.09 \sqrt{\text { Kil }}$ & 0.997 \\
\hline 6. & $\mathrm{KDK}=6.9+1.13(\mathrm{Ca}+\mathrm{Mg})+0.0700 \mathrm{Kil}-2.3 \sqrt{\mathrm{Ca}+\mathrm{Mg}}$ & 0.997 \\
\hline 7. & $\mathrm{OM}=-0.121-0.0234 \mathrm{Kil}+0.0508 \mathrm{KDK}+0.0172 \mathrm{Eğim}$ & 0.984 \\
\hline 8. & Kil $=26.4+3.38$ Kum - 10.8 Eğim & 0.779 \\
\hline 9. & Kil $=-52+8.2$ Kum -15.1 Eğim $-0.29(\text { Eğim })^{2}$ & 0.796 \\
\hline 10. & Kil $=-192+0.95$ Kum -17.2 Eğim $+65 \sqrt{\text { Kum }}$ & 0.799 \\
\hline 11. & Kireç $=2.9+0.124(\mathrm{Ca}+\mathrm{Mg})-0.073 \mathrm{Kil}-0.158$ Eğim & 0.553 \\
\hline
\end{tabular}

Yapılan araștırmalar, regresyon modellerinin toprak özelliklerinin karesi, kare kökü ve çarpımını kapsayan polinomlarla ifadesinin, regresyon katsayısını, dolayısıyla tahminin önem düzeyini yükselttiğini göstermektedir (Kosheleva vd., 2002; Gülser vd., 2007).

Diğer modellerde olduğu gibi, regresyon modellerinde de, gerçek ortamdaki parametreler arasındaki ilișkilerin ve karșııklı etkilerin detaylı matematiksel ifadesi mümkün olmamaktadır. Parametreler arasındaki fonksiyonel ilișkilerin belirlenmesinde, bazı sınırlamaların dahil edilmesi, regresyon modellerinin olumsuz yanı olmaktadır. Polinom fonksiyonların kullanılması, bu olumsuzluğun aradan kaldırımasına imkan sağlamaktadır.

\section{SONUÇ}

Yapılan bu çalıșmada, Samsun-Bafra karayolunun güneyinde, Engiz Beldesine bağı Dağköy mevkii içerisinde farklı topografik pozisyonlarda (tepe üstü düzlük, yamaç ve taban araziler) yer alan bazaltik ana materyal üzerinde olușmuș toprakların; fiziksel, kimyasal özellikleri belirlenmiș ve sınıflamaları yapılmıș; genetik horizonların topografik ve toprak özellikleri arasında doğrusal regresyon modelleri olușturulmuștur. Çalıșmada deniz seviyesinden 20-251 m arasında Kuzey-Güney kesiti üzerinde fraklı topografik pozisyonlardan toplam altı adet profil incelenmiștir. Toprakların gerek arazi morfolojik incelemeleri gerekse de alınan toprak örneklerinde yapılan labaratuvar analizler sonucu kesit üzerinde eğimli ve yamaç arazilerde yer alan topraklar Lithic Ustorthent alt grubunda sınıflandırıırken, düz düze yakın eğimli taban ve tepe/plato düzlüklerinde yer alan topraklar ise Typic Haplustert, Vertic Haplustept ve Typic Haplustept olarak sınıflandırımıștır. Aynı ana materyal olmasına karșın, aynı alan içerisinde bu denli faklı toprakların olușmasında diğer bir ifade ile geç ve olgun toprakların lokal bir alan içerisinde birlikte yer almalarının sebebi, topografya veya yerel rölyefin ana materyal ve zamanın toprak olușum süreç ve ișlemleri üzerinde önemli etkisi olduğudur. Ayrıca, bu duruma topraklarınüzerinde yer alan vejetasyonun sıklığı, çeșidi gibi faktörler de önemli etki yaptığı görülmüștür. Toprakların olgunlașmasında veya genç kalmalarında özellikle yamaç arazilerde yer alan topraklar da su hareketi dolaysıyla toprak tașınımı ve birikimi yerinde olușum kadar etkili olduğu görülmektedir.

Araștırma topraklarının B horizonuna ait 9. ve $C$ horizonuna ait 11. modellerde regresyon katsayıları orta; diğer tüm modellerde ise yüksek ve çok yüksek düzeyde olmaktadır. Dolayısıyla, elde edilen regresyon denklemleri, benzer özelliklere sahip olan toprakların $\mathrm{pH}, \mathrm{KDK}, \mathrm{OM}$, kil, kireç değerlerinin tahmininde kullanılabilir.

Genel olarak, toprak araștırmalarında elde edilen deneysel eğrilerin pratik olarak polinom fonksiyonlarla ifadesi mümkün olabilmektedir (Schaap, 2004). Araștırmanın amacına uygun olarak regresyon modelleri farklılık gösterdiğinden, farklı modellerin karșılaștırılması ve en iyisinin bulunması için genel bir kural olmamaktadır. 
Regresyon modellerinden hesaplanan teorik değerlerle, yerel, bölgesel veya global düzeyde olușturulmuș toprak verileri arasında karșılaștırılma yapılır ve modellerin yeterlilik düzeyi belirlenir. Bouma (1989)'a göre, regresyon modeller (pedotransfer fonksiyonlar) elde edilen verileri, gerekli verilere dönüștürmektedir. Regresyon modellerin uygulamasının kolaylığını göz önüne alarak, yerel ve bölgesel düzeyde bu modellerin yapılması için, uygun toprak verileri bankasının olușturulması güncel problemlerden biridir (Wösten vd., 1990; Shein ve Arkhangel'skaya, 2006).

\section{TESEKKÜR}

Bu çalıșmada kullanılan veriler 2130073 kodlu proje kapsamında yapılan çalıșmanın bir kısmını olușturmakta olup, tüm çalıșma TUBiTAK-TOVAG tarafından desteklenmiștir. Desteklerinden dolayı teșekkür ederiz.

\section{KAYNAKLAR}

Bayraklı F, Ekberli I, Gülser C (1999). Azerbaycan Mil ovası topraklarının verimlilik düzeylerinin deneysel ve matematiksel olarak değerlendirilmesi. Ondokuz Mayıs Üniversitesi Ziraat Fakültesi Dergisi, 14(2): 138-153.

Bosch A, Dörfer C, He JS, Schmidt K., Scholten T (2016). Predicting soil respiration for the Qinghai-Tibet Plateau: An empirical comparison of regression models. Pedobiologia, 59: $41-49$

Bouma J (1989). Using soil surve data for quantitative land evaluation. Advances Soil Science, 9: pp. 177-213.

Bouyoucous GJ (1951). A Recalibration of Hydrometer for Making Mechanical Analysis of Soils, Agronomy Journal, 43(9): 434-443.

Candemir F, Gülser C (2012). Influencing factors and prediction of hydraulic conductivity in fine-textured alkaline soils. Arid Land Research and Management. 26: 15-31.

Carlona C, Valleb MD, Marcominia A (2004). Regression models to predict water-soil heavy metals partition coefficients in risk assessment studies. Environmental Pollution, 127: 109-115.

Ekberli İ, Dengiz O, Özdemir N, Göl C (2009). Topraktaki tuz miktarı ile toprağın bazı fiziksel-kimyasal özellikleri arasındaki ilișilerin incelenmesi. International Research Conference "Priority line of activity in the industry and working over of an agricultural output" dedicated to 80-years old of the academician K.U.Medeubekov Kazakh National Agricultural University (Almatı. 22.05. 2009), s. 677-683.

Ekberli i, Kerimova E (2005). Azerbaycan'ın Șirvan bölgesinde sulanan killi bir toprağın bazı fiziksel-kimyasal parametrelerinin değișimi. Ondokuz Mayıs Üniversitesi Ziraat Fakültesi Dergisi, 20(3): 54-59.

Ekberli I, Kerimova E (2008). Functional relationships between fertility and some soil parameters. Asian Journal of Chemistry, 20(3): 2320-2326.
Gülser C (2004). Tarla kapasitesi ve devamlı solma noktasının toprakların fiziksel ve kimyasal özellikleri ile ilișkili pedotransfer eșitliklerle belirlenmesi. Ondokuz Mayıs Üniversitesi Ziraat Fakültesi Dergisi, 19(3): 19-23.

Gülser C, Așkın T, Özdemir N (2003). Ondokuz Mayıs Üniversitesi Kampus topraklarının erozyona duyarlııklarının değerlendirilmesi. Ondokuz Mayıs Üniversitesi Ziraat Fakültesi Dergisi, 18(1): 1-6.

Gülser C, Candemir F, İç S, Demir Z (2007). Pedotransfer modellerle ince bünyeli topraklarda doygun hidrolik iletkenliğin tahmini. V. Ulusal Hidroloji Kongresi. Orta Doğu Teknik Üniversitesi. Ankara. 5-7 Eylül 2007, s. 563-569.

Jackson ML (1958). Soil Chemical Analysis. Englewood Cliffs, New Jersey: Prentice Hall Inc.

Korolev VA (2008). Changes in the main physical properties of ordinary chernozems under the impact of irrigation. Pocvovedeniye, 10: 1234-1240.

Kosheleva NE, Kasimov NS, Samonova OA (2002). Regression models fort he behavior of heavy metals in soils of the Smolensk-Moskow upland. Pocvovedeniye, 8: 954-966.

Li F, Shan X, Zhang T, Zhang S (1998). Evaluation of plant availability of rare earth elements in soils by chemical fractionation and multiple regression analysis. Environmental Pollution, 102: 269-277.

Liu J, Chao-Fu W, Oian X, Wei-Hua Z (2014). Capacities of soil water reservoirs and their better regression models by combining "merged groups PCA" in Chongqing. China. Acta Ecologica Sinica, 34: 53-65.

Purtova LN, Zimina MP (2007). Variability of physicochemical characteristics of brown forest soils within the phytogenic fields of trees (the Southern Far east). Pocvovedeniye, 1: 31-37.

Qian J, Wang Z, Shan X, Tu O, Wen B, Chen B (1996). Evaluatıon of plant avallabılıty of soll trace metals by chemıcal fractıonatıon and multıple regressıon analysıs. Environmental Pollution, 91 (3): 309-315.

Rhoades JD (1986). Cation Exchange Capacity, Chemical and Microbiological Properties. Methods of Soil Analysis, Part II. Madison: ASA and SSSA Agronomy Monograph, No: 9.

Schaap MG (2004). Accuracy and unsertainty in PTF predictions. Development of pedotransfer functions in soil hydrology. Elsevier, p.33-43.

Shein EV, Arkhangel'skaya TA (2006). Pedotransfer functions: state of the art, problems, and outlooks. Pocvovedeniye, 10: 1205-1217.

Silva Chagas C, Carvalho Junior W, Barge Bhering S, Calderano Filho B (2016). Spatial prediction of soil surface texture in a semiarid region using random forest and multiple linear regressions. Catena, 139: 232-240.

Simon M, Garcia I (1999). Physico-chemical properties of the soil-saturation extracts: estimation from electrical conductivity. Geoderma, 90: 99-109.

Soil Survey Staff (1992). Procedures for Collecting Soil Samples and Methods of Analysis for Soil Survey. Soil Surv. Invest. Report, Washington D.C., USA: I. U.S. Gov. Print. 
Office.

Soil Survey Staff (1993). Soil Survey Manual, USDA Handbook, Washington D.C., No: 18.

Soil Survey Staff (1999). Soil Taxonomy. A Basic of Soil Classification for Making and Interpreting Soil Survey. USDA Handbook, Washington D.C., No: 436.

Soil Survey Staff (2004). Soil Survey Laboratory Methods Manual Soil Survey Investigations Report, USDA, No:42.

Thorntwaite CW (1948). An Approach to a Rational Classification of Climate. Geographic Review, 38: 55-94.

Utkaeva VF (2007). Specific surface area and wetting heat of different soil types in European Russia. Pocvovedeniye, 11 : 1336-1346.

Verachtert E, Van Den Eeckhaut M, Poesen J, Govers G, Deckers J (2011). Prediction of spatial patterns of collapsed pipes in loess-derived soils in a temperate humid climate using logistic regression. Geomorphology, 130: 185-196.

Wösten JHM, Schuren CHJE, Bouma J, Stein A (1990). Functional sensitivity analysis of four methods to generate soil hydraulic functions. Soil Sci. Soc. Am. J., 54: 832-836.

Yukselen-Aksoy Y, Kaya A (2010). Method dependency of relationships between specific surface area and soil physicochemical properties. Applied Clay Science, 50: 182190.

Zaydelman FR (1987). Meliorasiya pocv. İzdatelstvo Moskovskogo Universiteta, 304 s.

Zhumabekov EZh (2005). Physical and mechanical properties of soil in Kyrgyzia. Pocvovedeniye, 7: 851-858. 